\title{
REFORMED PRISONER OR PRISON REFORM?: AN ACCOUNT OF OSCAR WILDE'S CARCERAL WRITINGS (1895-1900)
}

\author{
Mohsen Gholami', Majid Yazdani²
}

\author{
'Islamic Azad University Science and Research Branch, \\ ${ }^{2}$ Department of English Language \& Literature, Ershad-Damavand University
}

\begin{abstract}
The present paper aims at sifting through Oscar Wilde's carceral/post-carceral writings: De Profundis (1905), The Ballad of Reading Gaol (1898), and The Daily Chronicle's letters (1897-8) in order to pinpoint how Oscar Wilde's literary voice, during incarceration, transformed from that of an aesthete, or a witty writer into an uncompromising prison reform activist, remaining actively engaged in mounting a propaganda tool against the desperate plight and hardship of the late nineteenth-century penal system, and accordingly, calling for the necessity of implementing major penal reformations as a retaliatory measure. The overriding question concerning this paper, therefore, will center on 'How prison reformed Oscar Wilde', and 'How Oscar Wilde reformed prison' from every conceivable angle to explore the fact that Oscar Wilde is worthy of consideration in the way in which he was affected in prison and solitary confinement and how he summoned strength to cope with the deprivations of prison life as well as implementing his recommendations to help reform prison, which were incorporated in the 1898 Prison Act.
\end{abstract}

Keywords: Oscar Wilde, Carceral Literature, Gross Indecency, Penal Reform, 1898 Prison Act. 


\section{Introduction}

On May 25th, 1895, Oscar Wilde ( Oscar Fingal O'Flahertie Wills Wilde) was prosecuted and assailed for the abominable crime of buggery and "gross indecency" ${ }^{1}$ (Smith, 1976, p. 165-173), as a consequence of the 'judicial conflict' (Hernen, 2013, p. 221) between him and Lord Alfred Douglas's ${ }^{2}$ father, the Marquess of Queensbury. As a result, this eminent and eccentric Irish writer, so acclimatised to luxury and the pleasures of social life, finds himself incarcerated (Stefanakou, 2015, p. 260) from 1895 to 1897. In the meanwhile, Oscar Wilde was handed down a determinate two-year sentence of hard labour, - 'a term that the Gladstone Committee (Cross, 1971, p. 3) judged to be more than a man could endure and that the $1898{\text { Prison } \text { Act }^{3} \text { would }}^{2}$ ultimately abolish (Bailey, 1997, p. 289). Wilde was, initially, sent to Newgate Prison in London for processing, thereupon followed by a brief stay in Pentonville Prison (May 25-July 4, 1895; May 1819, 1897), where the 'hard labour' (Fig. 1) to which he had been sentenced consisted of many hours of 'walking a treadmill'4 (Fig. 2), and 'picking oakum's (Fig. 3), and where prisoners were permitted solely to wade through the Bible, hymns and The Pilgrim's Progress. After a while, he was relocated to Wandsworth Prison (July 4-November 20, 1895) in London. Inmates there also adhered to the stringent regimen of "Hard Labour, Hard Fare and Hard Bed" 6 (Williams, 2009), which wore harshly on Wilde's delicate health. In November, he collapsed during chapel from insomnia, hunger, and disease. His right eardrum was ruptured in the fall, an injury that later contributed to his tragic death (Robins Sellars, 2000, p.1841-2).

On 23 November 1895, Richard B. Haldane, the Liberal MP and reformer, visited Wilde and had him transferred to Reading Prison (Reading Gaol/Jail)

(November 20, 1895-May 18, 1897).

As Baily states:

An attack of dysentery put Wilde into the prison infirmary for two months and led to some improvement in his dietary lot. Additional relief came in the shape of the Liberal lawyer, R. B. Haldane, who, as a member of the Gladstone Committee, had the authority to enter any prison and make the governor produce any prisoner. He visited Wilde in Pentonville and agreed to get him books of his choice. He also visited the prisoner in Wandsworth and subsequently persuaded the home secretary to transfer Wilde to Reading. (Bailey, 1997, p. 289)

The transfer itself was the lowest point of his incarceration, as a crowd jeered and spat at him on the railway platform (Ellmann, 1988, p. 465). Wilde had courted controversy and even notoriety, but bringing the family name to disgrace was a source of shame. In prison, 'Oscar Wilde' was replaced by a functional label, 'C.3.3' embrace this, and it would become the first nom de plume he used after leaving prison, when The Ballad of Reading Gaol was published (Hernen, 2013, p. 224). 


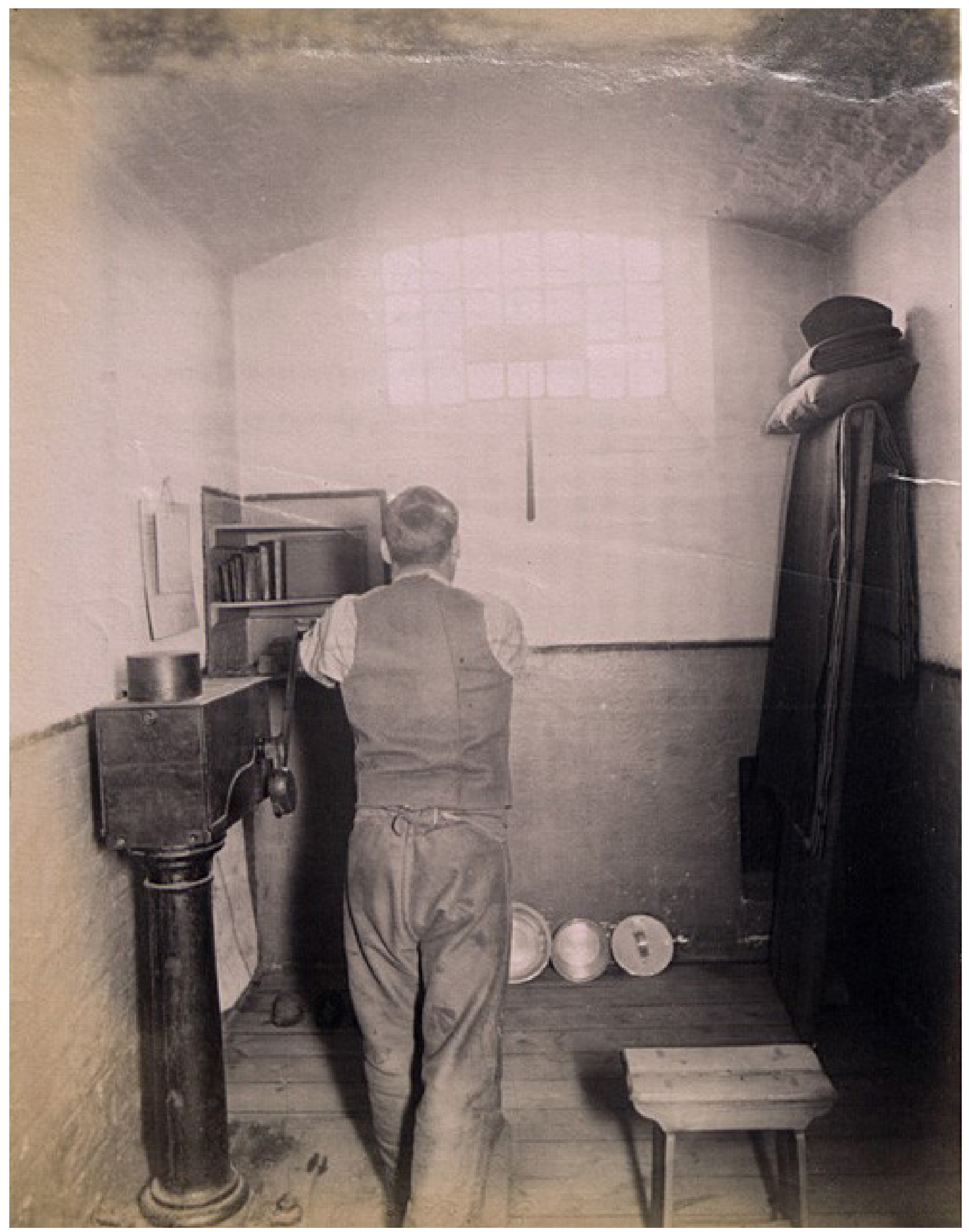

Figure 1. Photograph of prisoner at hard labour in his cell at Wormwood Scrubs Prison (COPY 1/420 f171) 

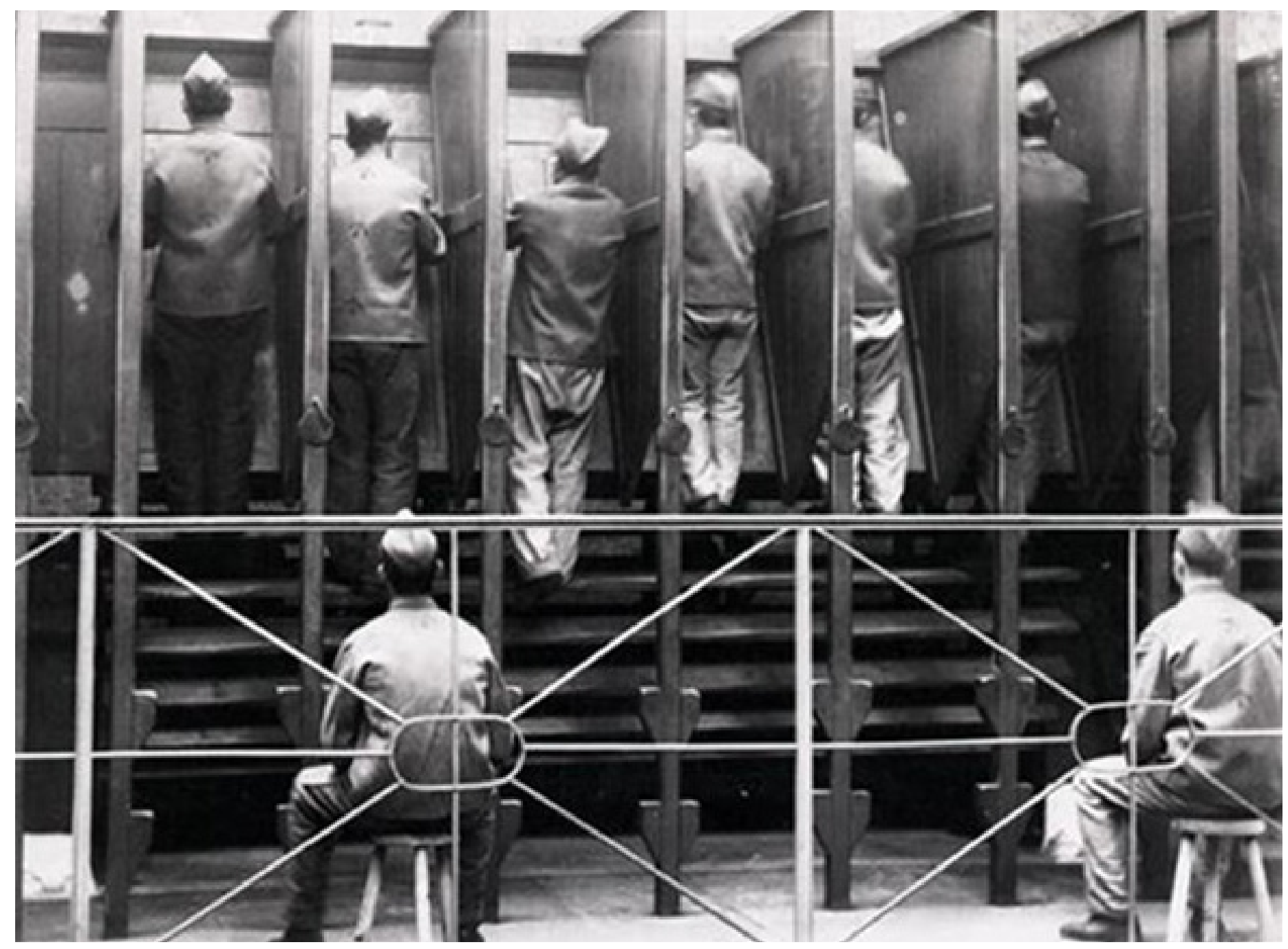

Figure 2. Prisoners on a treadwheel at Pentonville Prison 1895 (COPY 1/420)

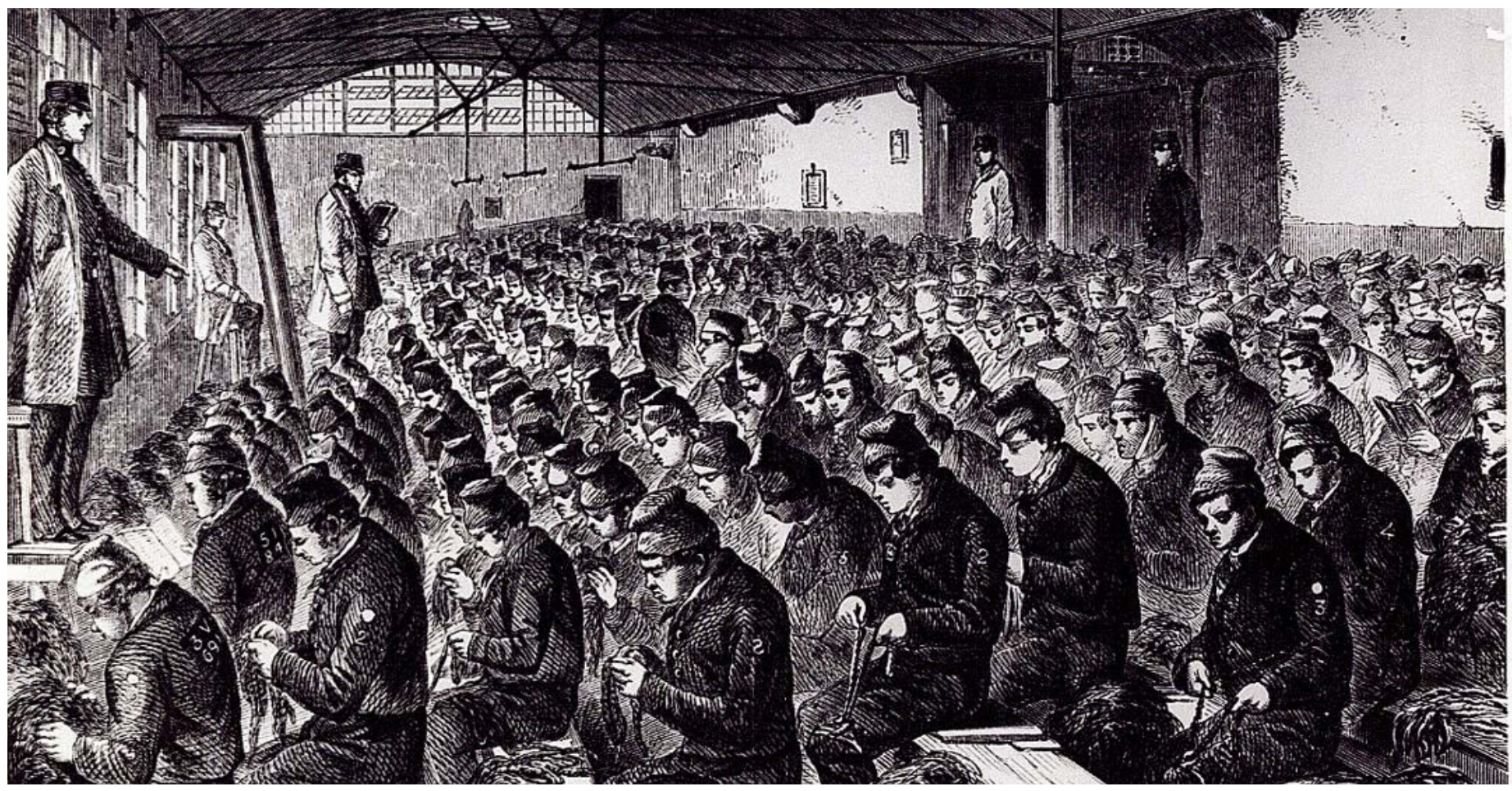

Figure 3. Prisoners picking oakum 


\section{An Intention to Reform}

The unjust arrest and subsequent two tumultuous years' confinement of Oscar Wilde were the most sensational and highly debatable episodes of the late Victorian epoch (1895-1901), with far-reaching social and cultural implications. But worse than losing his reputation and becoming pilloried, however, Wilde never again recuperated the considerable success of his pre-carceral career, but after being released in May 1897, he turned his hidden talents toward giving an account of the deliberate cruelties of prison life and the dreadful image of the late Victorian prison. Wilde neither obliterated his prison traumatic experience from his mind nor the on-going hardships of those he met during his incarceration (Housden, 2006, p. 44).

Prison had irreversibly transformed Wilde and his sentiments, likewise, were tantamount to being revolutionary and iconoclastic. He could not return to singing the praise of beauty and pleasure. Nor could he re-create the success of his comedies, mocking at society with his paradoxes whilst forcing respectable audiences to laugh at their cherished hypocrisies.

But moreover, Wilde had to heighten his philosophy to include what he had endured, to make use of sorrow as well as joy. He writes from the prison of his new outlook (Williams, 2009):

[R]eason does not help me. It tells me that the laws under which I am convicted are wrong and unjust laws, and the system under which I have suffered a wrong and unjust system. But, somehow, I have got to make both of these things just and right to me... . I have got to make everything that has happened to me good for me. The plank-bed, the loathsome food, the hard ropes shredded into oakum till one's fingertips grow dull with pain, the menial offices with which every day begins and finishes, the harsh orders that routine seems to necessitate, the dreadful dress that makes sorrow grotesque to look at, the silence, the solitude, the shame -- each and all of these things I have to transform into a spiritual experience.

$$
\text { (Wilde, 2007, p.1073-4) }
$$

This was, in essence, the reformatory ideal of the penitentiary turned on its head. He would seek out, or create a vantage point from which prison would be good for him -- not by the standards of society, but by his countermeasures or 'self-fulfilling prophesy'. He would turn his disgrace into a triumph.
And the prison would not reform him; he would reform the prison, (Williams, 2009) as "It is not the prisoners who need reformation. It is the prisons." (Wilde, 1999).

Wilde expresses this intention in a note that still survives. It is penned on a small scrap of an envelope, the front of which is marked 'Private' and addressed to Major Nelson, the Governor of Reading Gaol (Williams, 2009). On the back Wilde wrote:

I hope to write about prison-life and to try and change it for others, but it is too terrible and ugly to make a work of art of. I have suffered too much in it to write [a] play about it. ${ }^{8}$

This is the perspective from which we must deepen our understanding 'How prison reformed Oscar Wilde' and 'How Oscar Wilde reformed prison' through a thoroughgoing deconstructive analysis of his carceral and post-carceral texts: De Profundis (1905)-a letter addressed to the British penal society of the late nineteenth century, The Ballad of Reading Gaol (1898) - a long poem reflecting the harsh rhythms of prison life, followed by two agitation letters to the editor of the Daily Chronicle (1897-1898) describing the brutalisation of English prisons and his concerns over the maltreatment of children in prisons, and generating a decisive force for penal reform.

Following a root and branch penal reform, Oscar Wilde casts a shaft of light on some resonant and fiercely contentious issues in prison that the championship for prison reform would last whatever the terrible cost ("I have no doubt we shall win, but the road is long, and red with monstrous martyrdoms [...] It is not so much public opinion as public officials that need educating". (Stokes, 1996, p.81)). This supports the idea that incarceration did change Wilde's views and narratives into becoming highly political and critical of the unaccustomed, prolonged institutional constraints, its unendurable living conditions as well as maltreatment towards inmates. The strength of the article, therefore, lies in the fact that Oscar Wilde is worthy of reconsideration of the way how he was affected by prison and how he found the strength to overcome insurmountable barriers of prison life as well as implementing enforceable recommendations to instigate a programme of prison reforms. 


\section{Confessional Letters Written in Prison}

\section{De Profundis (1905) ${ }^{9}$}

"It is difficult for most people to grasp the idea. I dare say one has to go to prison to understand it. If so, it may be worthwhile going to prison."

$$
\text { - Oscar Wilde (De Profundis, 1905) }
$$

The circumstances surrounding Oscar Wilde's incarceration and the writing of De Profundis are conceivably the most singular of any in this volume. Ultimately, he was criminalised as part of Victorian England's heavy-handed policing of sexual activity between men. It would seem, however, that this was a situation he might have avoided, had he not first pursued a lawsuit of his own-against the man who then became the accuser in his criminal case. Irrespective of the possible hubris that may have brought Wilde to prison, the experience was intense and horrific (Portanova, 2015). De Profundis, edited and posthumously published in 1905, is a long, harrowing, and yet lacerating letter written by Oscar Wilde between January and March 1897, close to the end of his incarceration, in Reading Gaol. The letter was scripted on "blue stamped prison foolscap paper" (Hernen, 2013, p. 223) administered to Wilde, apparently one page at a time, after a long period during which he had been denied books, pen and paper. Despotic prison authorities banned him to send the completed work directly to his former lover, Lord Alfred Douglas, in which he writes:

I have lain in prison for nearly two years. Out of my nature has come wild despair; an abandonment to grief that was piteous even to look at; terrible and impotent rage; bitterness and scorn; anguish that wept aloud; misery that could find no voice; sorrow that was dumb.

(Wilde, 2007, p. 1071)

Indeed, these 'confessional modes of writing transmit the personal experience of imprisonment' (Jarrin, 2008, p.93) and reveal how Wilde was put under the pressure of incarceration imposed by the restrictive and authoritarian Victorian society and staged an angry outcry against the unlawful, draconian judicial system of the late nineteenth century. Furthermore, Oscar Wilde laments the complete absence of humanity in late Victorian society:
Many men on their release carry their prison about with them into the air, and hide it as a secret disgrace in their hearts, and at length, like poor poisoned things, creep into some hole and die. It is wretched that they should have to do so, and it is wrong, terribly wrong of society that it should force them to do so. Society takes upon itself the right to inflict appalling punishment on the individual, but it also has the supreme vice of shallowness, and fails to realise what it has done. When the man's punishment is over, it leaves him to himself; that is to say, it abandons him at the very moment when its highest duty towards him begins. [...] I can claim on my side that if I realise what I have suffered; society should realise what it has inflicted on me; and that there should be no bitterness or hate on either side.

(Wilde, 2007, p. 1075)

On a brighter note, he remarks:

"The two great turning-points in my life were when my father sent me to Oxford, and when society sent me to prison" (Wilde, 2007, p. 1074).

But, this thorny question needs to be queried about 'the whys and wherefores of this letter'. The assumption could be that this is primarily a private letter revealing the true self, in which the first person singular ('I') is frequently used, while Wilde was hidden away from the world (Hernen, 2013 , p. 224). Consequently, the text, written in a melancholy manner, has been seen as a propaganda tool against the abysmal prison conditions to expose the desperate plight and hardship of the nineteenthcentury penal institutions, and how much the penal system necessitated an immediate reformative programme at the time.

De Profundis includes Wilde's stated uncrushable intention of trying to castigate the strongly-flowing disciplinarian tide of the English penal system for its exclusive emphasis on deterrence as the principle for reducing crime and reforming either first-time offenders or habitual criminals (Taylor, 2011, p. 8). As he declares:

"Prison style is absolutely and entirely wrong. I would give anything to be able to alter it when I go out. I intend to try" (Wilde, 2007, p. 1092).

As a prisoner, he faces the hideous reality of being a dejected prison inmate. As he distinctively states:

The plank bed, the loathsome food, the hard ropes shredded into oakum 'till one's fingertips grow dull 
with pain, the menial offices with which each day begins and finishes, the harsh orders that routine seems to necessitate, the dreadful dress that makes sorrow grotesque to look at, the silence, the solitude, the shame-each and all of these things I have to transform into a spiritual experience.

(Wilde, 2007, p. 1073)

More interesting still, is the fact that Wilde broaches the subject of prison life in a controversial and paradoxical way, which could question whether he was seeking the positives or the negatives through the vicissitudes of prison life. As he expresses:

I have had a year longer of imprisonment, but humanity has been in the prison along with us all, and now when I go out I shall always remember great kindnesses that I have received here from almost everybody and on the day of my release I shall give many thanks to many people, and ask to be remembered by them in turn.

(Wilde, 2007, p. 1092)

On the downside, languished in Reading Gaol for six weeks, Wilde heard someone murmur: "Oscar Wilde, I pity you because you must be suffering more than we". Wilde replied: "No, my friend, we are all suffering equally" (Stokes, 2007, p. 83).

It certainly sounds plausible that the Victorian penal system was supposed to act as much of a 'deterrent to criminals' ${ }^{10}$ not to reconvict rather than provide them with the physical and emotional well-being, and this system also conveys the message to potential offenders to feel disinclined to offend. According to Wilde, it appears to be a foregone conclusion that the inevitable corollary of prison life with its unrelenting pressures and tight constraints make offenders become increasingly defiant and rebellious:

For prison life with its endless privations and restrictions makes one rebellious. The most terrible thing about it is not that it breaks one's heart hearts are made to be broken-but that it turns one's heart to stone.

(Wilde, 2007, p. 1079)

Another overemphasized issue Wilde points out is the importance of censorship of letters and the question of authorship (C.3-3). The letters, penned during imprisonment, must not reveal the exact description of the horrors and the deprivation of prison life, under Victorian England's prison systems (the 'silent' or 'associated' system and the 'separate' system) (Cross, 1971, p. 9). It is self-evident that Wilde's letters were partially censored to conceal the truth, due in part to being deemed morally and ethically offensive, or by implication, politically provocative or menacing. As he states:

"Here I have the horror of death with still greater horror of living: and in silence and misery [here about four lines are cut out with scissors by the censor]" (Dulau \& Co, 1920, p. 20).

It is, therefore, perceptible why Wilde cursorily had his highly polemical letters published after his release, as he could tell an uncensored and circumstantial account of his imprisonment and vented his spleen against the immoral, anachronistic prison system.

\section{Poetry Written Outside of Prison Walls}

\section{The Ballad of Reading Gaol (1898) $)^{11}$}

That every prison that men build

Is built with bricks of shame,

And bound with bars lest Christ should see

How men their brothers maim.

- Oscar Wilde

(The Ballad of Reading Gaol, 1897)

After being released from Reading Goal, Wilde wrote The Ballad of Reading Gaol whilst residing in France in 1898. This poem, in particular, infatuated readers as it was nothing like anything Wilde had written before, and albeit a free man, the content of the poem reflects just how broken down he is after his distressing experience as an inmate. Firstly, upon its publication, the poem was not under Wilde's name; instead, it was titled with his prisoner number (C.3$3)$, which suggests a loss of identity within the prison where everyone is a prisoner, irrespective of their success or upbringing.

It is significant to note that Wilde means to depict the harsh realities of prison on an individual and by using his anonymous prisoner number to title the poem he strives to elucidate how bureaucratic administrators of a punitive system aim to grind the prisoners down and encroach upon their rights and freedoms. In response, Wilde exposes the old excuse of those servants of power who hide behind a mask of unswerving loyalty (Paul, 2008, p. 33):

The Governor was strong upon the 
The Regulations Act:

(Buckler, 1990, p. 33)

The Doctor said that Death was but

A scientific fact:

And twice a day the Chaplain called,

And left a little tract.

(Wilde, 1999, p. 123)

It is, but assuredly and abundantly clear that Wilde was hauntingly and elegiacally inspired by the execution of Charles Thomas Wooldridge, a 30-year old soldier serving in the Royal Horse Guards and stationed at Regents' Park barracks ${ }^{12}$ ("They hanged him as a beast is hanged" (Wilde, 1999, p. 134)), as he seeks human morality and the commiseration to mankind throughout the entirety of the poem. It also touches upon the seemingly intractable issues surrounding the death penalty and the sordidness of the English penal system but seems to circulate round Wilde's personal experiences.

He does so by reflecting on how prison seems to provoke a sense of permanent alienation from society. Whether someone is guilty or wrongly accused, the harsh inhumane and barbarous conditions, and the deprivation of prison life was excruciating enough to degrade/relegate irredeemable inmates rather than lead them into the right direction of being genuinely law-abiding characters. Wilde's views undoubtedly reflect the salient fact that it is not the prisoners who should feel the shame of being in jail, but the society's punitive attitude that put them there(Wilde, 2007, p. 1075).

The prisoners were a mere product of what was wrong with society, and that finding one's fate within the walls of prison could happen to anyone. He firmly believes that the general public is oblivious to the events, reflecting the grim reality of prison conditions ("And they do well to hide their Hell" (Wilde, 1999, p. 135)). In broad terms, Wilde is not necessarily blaming the laws which made him imprisoned, but the way the penal system enforced by the people who have power into their hands and can inflict unfitting punishments on others instead of having controlled punishment for unpardonable offences. As William Buckler, as a supportive view, writes:

The poem suggests that the fact that society has not defined those other kinds of deadly offences and fixed punishments for them should make thoughtful people less self-righteous, rigid and relentless... in putting down offenders against the rules society happens at a given moment to have formulated.
In greater detail, what Wilde depicts in this poetic ballad is how the penal system became inhumane and needed to be overhauled, as he expresses his mindset towards the fundamentally flawed penal system and laws: "I know not whether Laws be right" (Wilde, 1999, p.135). This line reflects that "No attempt is made to assess the justice of the laws which convicted them, but rather the poem highlights the brutalisation of the punishment that all convicts share" (Sandulescu, 1994, p. 310).

But, this brings up a probing question about the whys and the wherefores of The Ballad of Reading Gaol'. Peter Stoneley states: "The Ballad was written in part to campaign against the cruelty of the prison regime" (Stoneley, 2014, p. 477). The truth is that Oscar Wilde in The Ballad of Reading Gaol uses a scathing attack on the Victorian penal policy-making and administration, the horrendous conditions and the tormenting feelings of prison life from which he and the other inmates of English prisons suffered, and the monotonous, unproductive hard labour they had to do through a "foolish and inhuman code" (Wilde, 1999) of punishment under the 1885 Amendment Act to make them reformed through 'Humanity's machine'. As the Ballad goes:

Each narrow cell in which we dwell Is a foul and dark latrine, And the fetid breath of living Death Chokes up each grated screen, And all, but Lust, is turned to dust In Humanity's machine.

(Wilde, 1999, p. 136)

Wilde's incarceration changed his mind and outlook about the need to draw the attention of the public to the appalling conditions of the convicts, or, more precisely, the way the iniquitous penal system is enforced. He is no more an aesthete or a witty writer, but a self-proclaimed revolutionary prison activist, calling for the urgent need for change. As Ellman writes:

"He knew that it must fall between poetry and propaganda and that the strength of the poem lay in its ballad narrative" (Ellmann, 1988, p. 500).

And, Sherard also writes: "I think that one of the few serious purposes he had in life when he left prison was to try to do something to reform the English 
wrongful prison system" (Sherard, 1916, p. 395).

OscarWilde, evidentially, became "uncompromisingly political"13 and strongly critical of the unjust penal system, the tormenting conditions of prison life and the maltreatment of inmates. The descriptions of such relentlessly harsh conditions can be exemplified throughout his poem, as the reference to the 'iron gin' and 'Gyves' ${ }^{\prime 4}$ (Stokes, 2007, p. 111). These conditions in which the incorrigible prisoners were impelled to inhabit were both animalistic and inhumane, due mainly to the unjustified punishments, mindless brutality, and high-level corruption which took place. As Jarrin states in his essay:

Although Wilde's eulogistic Ballad of Reading Gaol, dedicated to fellow inmate Charles Thomas Wooldridge, staged a contemporaneous critique of the inhumanities of internment within the British system, his prison and post-prison letters engaged most directly with the movement for penal reform.

(Jarrin, 2008, p. 94-95)

This provides compelling evidence that Wilde was using the poem as a way of reflecting his own salutary experience and opening the eyes of his readers to the cruel reality of the highly secretive and undemocratic society they were living in. The poem is Wilde's way of outing the corruption of not only the prison system but also society. As Buckler states in his article:

The Ballad of Reading Gaol is a poetic lament over what 'man has made of man,' and its subject is the cruelty that is unintentionally released when society substitutes for individuals with professional expertise, humane feelings, and common sense a stereotyped system of hard-and-fast rule.

(Buckler, 1990, p. 34)

To promulgate his long-running anti-carceral propaganda, preceded by the success of his Ballad, Wilde's overtly political aims were at their most explicit, ensued from two letters to the Daily Chronicle, which present extended critique of dreadful prison life within Reading Prison that goes unnoticed by the public.

\section{Campaign Letters Written Outside of Prison Walls}

\section{The Daily Chronicle Letters (1897-1898)}

A year after his release in 1989, when The Ballad of Reading Gaol had already been published, Wilde composed two lengthy devastating letters to the editor of London's Daily Chronicle newspaper (H.W. Massingham), titled under the unequivocal headings: 'The Case of Warder Martin: Some Cruelties of Prison Life' on 18th May 1897, and 'Don't Read This, if You Want to Be Happy Today' on 24th March 1898, addressing the demoralising effect of "awful" carceral silence, and outlining a litany of "inhuman" tortures inflicted upon the modern prisoner within the "stupid and barbarous" British penal system. From the outset, Wilde, in effect, denounces the innumerable faults, the inhumane prison conditions as well as the maladministration and negligence of the prison staff. He, in return, adopts a quasiunorthodox approach for "what should be done" to ameliorate the "present system" through prescribing a series of "urgently necessary" reforms in contriving to rectify these perennial issues (Jarrin, 2008, p. 95). According to Wilde's diagnosis, inmates of English prisons were systematically deprived of the most basic "needs of the body and the needs of the mind" (Wilde, 1999). Also, "prisoners were denied access to adequate food, sanitary conditions, sleep, books, and regular visitors" (Jarrin, 2008, p. 90). With regard to mental stimulation, Wilde proposes the ensuing permanent punishments, authorised by law in English prisons, superseded by some workable resolutions (Table. 1 ) (Wilde, 1999). 
Table 1. Oscar Wilde's Carceral Reforms

\begin{tabular}{|c|c|c|}
\hline & PUNISHMENTS & RESOLUTIONS \\
\hline HUNGER & $\begin{array}{l}\text { The food supplied to prisoners is entirely } \\
\text { inadequate. }\end{array}$ & $\begin{array}{l}\text { The food given to children should consist of } \\
\text { tea and bread-and-butter and soup. }\end{array}$ \\
\hline INSOMNIA & $\begin{array}{l}\text { The object of the plank bed is to produce } \\
\text { insomnia. }\end{array}$ & \\
\hline DESEASE & $\begin{array}{l}\text { The present prison system seems almost to } \\
\text { have for its aim the wreching and the de- } \\
\text { struction of 'the mental faculties'. }\end{array}$ & \\
\hline BOOKS & $\begin{array}{l}\text { Deprived of books of all human intercourse, } \\
\text { isolated of every humane and humanizing } \\
\text { influence. }\end{array}$ & $\begin{array}{l}\text { Every prisoner shoud have an adequate } \\
\text { supply of good books. }\end{array}$ \\
\hline VISITS & $\begin{array}{l}\text { Under the present system, a prisoner is } \\
\text { only allowed to see his friends for times a } \\
\text { year, for twenty minutes each time. }\end{array}$ & $\begin{array}{l}\text { A prisoner should be allowed to see his } \\
\text { friends once a month, and for a reasonable } \\
\text { time. }\end{array}$ \\
\hline LETTERS & $\begin{array}{l}\text { At present one is allowed to write only for } \\
\text { times a year. }\end{array}$ & $\begin{array}{l}\text { Every prisoner should be allowed to write } \\
\text { and recieve a letter at least once a mont. }\end{array}$ \\
\hline IMPRISONED CHILDREN & $\begin{array}{l}\text { Children sit behind a curtain in chapel, and } \\
\text { are sent to take exercise in small, sunless } \\
\text { yard sometimes a stone-yard, sometimes a } \\
\text { yard at the back of the mills. }\end{array}$ & $\begin{array}{l}\text { They should be in a workshop or a school- } \\
\text { room with a warder. }\end{array}$ \\
\hline $\begin{array}{l}\text { SOLITARY } \\
\text { CONFINEMENT }\end{array}$ & $\begin{array}{l}\text { Indeed in prisons all over the world where } \\
\text { the system of silence and cellular confine- } \\
\text { ment is practised. I refer to the large num- } \\
\text { ber of men who become insane or } \\
\text { weak-minded in prison. }\end{array}$ & $\begin{array}{l}\text { Kind words are much in prison, and a pleas- } \\
\text { ant "Good morning" or "Good evening" will } \\
\text { make one as happy as one can be in solitary } \\
\text { confinement. }\end{array}$ \\
\hline
\end{tabular}

What Wilde addresses in the letter to The Daily Chronicle is the "increase in number of inspectors and official visitors" and states that "when he speaks to his friends through the bars of the cage, or the aperture of the wooden box, he is brutalised by the warders' (Wilde, 1999). He, then, turns his attention to the inspectors and justices of the peace, which Wilde ironically made the proposition that visiting prisons are un purposefully done without having any clauses altered or regulated for the disturbed inmates. As the letter goes:
The inspectors and justices of the peace that visit prisons come there for the purpose of seeing that the prison regulations are duly carried out. They come for no other purpose, nor have they any power, even if they had the desire, to alter a single clause in the regulations.

(Wilde, 1999)

Wilde, in fact, believes that such inspections and supervision deteriorate the existing situation for the inmates. As he reiterates: 
A prisoner who has been allowed the smallest privilege dreads the arrival of the inspectors. And on the day of any prison inspection the prison officials are more than usually brutal to the prisoners ... to show the splendid discipline they maintain.

(Wilde, 1999)

In his campaign letter, Wilde, to take a final example, draws his undivided attention to the overemphasis on books for the traumatised inmates and their role in preserving mental health to avoid causing detrimental psychological outcomes, such as depression, insanity, and mental/physical incapacity. Wilde manifestly states that prisoners were also deprived of ordinary human and social intercourse, and alienated from every humane and humanising influence. He highlights that prisons must equip prisoners with a miscellaneous collection of books, especially literary books to preserve prisoners' mental health rather than merely suffice holy books or sacred writings. Furthermore, Wilde shares the belief that hapless offenders, notably psychiatrically disturbed children and adults, should be educated and supplied with reading and writing materials: "Prisoners should be encouraged to read, and should have whatever books they want, and the books should be well chosen. At present, the selection of books is made by the prison chaplain" (Wilde, 1999).

\section{As Jarrin quotes:}

Wilde calls specific attention to inadequate, atrophied, and 'perfectly useless' prison libraries as an extension of the deprivations of the silent system; these libraries offered inmates little more than 'a Bible, prayer-book, and hymn-book' and 'third-rate, badly-written, religious books . . . utterly unsuitable for children or for anyone else'.

(Jarrin, 2008, p. 95)

In a very real sense, Wilde's forceful advocacy and full-fledged movement of prison reform seem to have provided some new impetus for the unscrupulous Victorian society and the repressive judicial system of the nineteenth century, which ultimately culminated the 1898 Prison Act. ${ }^{15}$ As Christopher Millard later reports:

It is related on undeniable authority that the Commissioners appointed to inquire into the question of Prison Reform in the years 1897 and 1898 spent three days considering the suggestions made in Wilde's letters, with what good results may very briefly be stated as follows: At the end of the first month's imprisonment a prisoner is allowed to write a letter or to receive a visit, and to read a book, instead of waiting three months as formerly; the sanitary arrangements have been improved; the food weighed out each day is somewhat less scanty and more varied; [and] the plank bed is insisted on for the first fourteen days only, instead of a month.

(Millard, 1908, p. 638)

Hence, as a result of being an oppressed and marginalized captive in the Victorian society, it is crystal clear how Wilde sufficiently crossed the threshold of criminality to characterise himself as being an undeterred liberated champion of prisoners' rights movement, and subsequently, condemned the pointless cruelties of prison and the unjust penal system for their exploitative modes against inmates. As he points out, the prime focus of the present prison system is to produce insanity for inmates as they have to face the dire consequences: "The present prison system seems almost to have for its aim the wrecking and the destruction of the mental faculties. The production of insanity is, if not its object, certainly its result" (Wilde, 1999). To ameliorate the existing prison system at the time, Wilde's second letter proposes a complete overhaul and focuses attention on the structures of the incompetent penal authorities creating such deplorable conditions and practices for him and the inmates alike. As he states: "the first, and perhaps the most difficult task is to humanise the governors of prisons, to civilise the warders and to Christianise the chaplains" (Wilde, 1999).

\section{Summing up}

On May 25th, 1895, Oscar Wilde was sentenced to prison for two years' hard labour on the charges of "gross indecency" with other men, in which his career, family relationships, and reputation were greatly tarnished after the revelation. In the simplest terms, Wilde was at the apex of his career, having found phenomenal success in his latest play, The Importance of Being Earnest (1895), but this was tragically cut short by his incarceration.

In the present paper, it has been shown... nothing can alter the fact that prison changed the poetic, linguistic style beyond all recognition Wilde was renowned for and converted him into an indefatigable political dissident waging a vigorous campaign for the wellbeing of prisoners, who immeasurably suffered years 
of ostracism. For this reason, Wilde endeavors to accentuate the major flaws in the Victorian penal system, and accordingly, recommends a number of constructive measures to reform it. Notwithstanding being repudiated, condemned and persecuted, many of Wilde's recommendations to help reform prison were incorporated in the 1898 Prison Act, which led to the abolition of the separation of prisoners, the removal of hard labour plus other substantial modifications pertaining to prisoners' rights (see Table. 1). Oscar Wilde, from this perspective, immerses himself in writing his carceral texts (i.e. protest literature written from prison) to highlight that not only can the existing prison environment have a profound and negative impact on the physical, mental, and emotional well-being of inmates, but also the new penitentiary system must institute a series of sweeping reforms to restrain them from becoming self-destructive or attempting suicide.

\section{Acknowledgements}

We are not only insufficiently appreciative of all the information and images under the title of 'Victorian Prisons \& Punishments', provided by The National Archives, which greatly equipped our manuscript, under the permission of 'All content is available under the Open Government Licence v3.0', but also are immensely grateful to A.J.W. (Tony) Taylor, an Emeritus Professor of Psychology at Victoria University of Wellington, for The 2011 Quaker Lecture, 'CHANGING THE PRISON SYSTEM', published by The Religious Society of Friends in Aotearoa, New Zealand. 


\section{References}

» Bailey, V. (1997). English Prisons, Penal Culture, and the Abatement of Imprisonment, 1895-1922. Journal oWf British Studies, 36(3), 285-324. https://doi.org/10.1086/386138

» Buckler, W. E. (1990). Oscar Wilde's "chant de cygnet": "The Ballad of Reading Gaol" in Contextual Perspective', Victorian Poetry. Vol. 28, No. 3/4, The Nineties.

»Cross, R. (1971). Punishment, prison and the public; an assessment of penal reform in twentieth century England by an armchair penologist. Volume 23 of Hamlyn lectures, London. Stevens \& Sons.

»Ellmann, R. (1988). Oscar Wilde. Penguin Books Ltd; New edition.

» Hernen, E. (2013). Names are Everything: For Oscar Wilde, Posing as a Letter and Visiting Card. https:// open.conted.ox.ac.uk/resources/documents/names-are-everything-oscar-wilde-posing-letter-andvisiting-card-elaine-hernen.

» Housden, M. (2006). 'Oscar Wilde's imprisonment and an early idea of "Banal Evil"' or 'Two "wasps" in the system. How Reverend W.D. Morrison and Oscar Wilde challenged penal policy in late Victorian England.' Retrieved December 23, 2019, from https://www.researchgate.net/publication/26544603_Oscar_ Wilde's_imprisonment_and_an_early_idea_of_Banal_Evil_'or_'Two_wasps_in_the_system_How_ Reverend_WD_Morrison_and_Oscar_Wilde_challenged_penal_policy_in_late_Victorian_England' Jarrin, C. A. (2008). You Have the Right to RefuseSilence: Oscar Wilde's Prison Letters and Tom Clarke's Glimpses of an Irish Felon's Prison Life. Retrieved from https://www.researchgate.net/publication/236705532_You_ Have_the_Right_to_Refuse_Silence_Oscar_Wilde's_Prison_Letters_and_Tom_Clarke's_Glimpses_of_an_ Irish_Felon's_Prison_Life

» Jarrin, C. A. (2008). You have the right to refuse silence: Oscar Wilde's prison letters and Tom Clarke's Glimpses of an Irish Felon's Prison Life. Eire-Ireland, Vol. 43, pp. 85-117. https://doi.org/10.1353/eir.0.0018 Millard, C. S. (1908). The Athenaeum. London British Periodicals. University of Toronto. https://archive. org/details/p1athenaeum1908lond.

» Paul, R. (2008). "[U]ngrateful, discontented, disobedient, and rebellious": Subaltern Voices in the Writings of Oscar Wilde. Nordic Journal of English Studies. ojs.ub.gu.se/ojs/index.php/njes/art. Portanova, J. J. (2015). Great Books Written in Prison: Essays on Classic Works from Plato to Martin Luther King, Jr. http://publicism.info/writing/prison/7.html.

» Robins, A. H., \& Sellars, S. L. (2000). Oscar Wilde's terminal illness: Reappraisal after a century. Lancet, Vol. 356, pp. 1841-1843. https://doi.org/10.1016/S0140-6736(00)03245-1

» Sandulescu, C.-G., \& Princess Grace Irish Library. International Conference (5th: 1993: Monaco). (1994). Rediscovering Oscar Wilde. C. Smythe.

» Sandulescu, G. C. (1994). Rediscovering Oscar Wilde - Rowman \& Littlefield publisher. Retrieved from https://www.pinterest.com/pin/424182858653867194/

» Sherard, R. H. (1916). The real Oscar Wilde: To be used as a supplement to, and in illustration of "The life of Oscar Wilde": with numerous unpublished letters, facsimiles, portraits and illustrations. London: T. Werner Laurie.

» Smith, F. B. (1976). Labouchere's amendment to the Criminal Law Amendment bill. Historical Studies, 17(67), 165-173. https://doi.org/10.1080/10314617608595545

»Stefanakou, F. (2015). [PDF] Images of prison in Oscar Wilde's The Ballad of Reading Gaol | Semantic Scholar. Retrieved December 22, 2019, from https://www.semanticscholar.org/paper/Fioroula-Stefanakou-2015Images-of-prison-in-Oscar/5917e46de784739b1cea019236e2fae3d1c6357c

»Stokes, A., \& Dalrymple, T. (2007). Pit of shame: the real ballad of Reading Gaol. Waterside Press.

» Stokes, J. (1996). Oscar Wilde: myths, miracles, and imitations. Cambridge University Press.

» Stoneley, P. (2014). Looking at the others: Oscar Wilde and the reading gaol archive. Journal of Victorian Culture, 19(4), 457-480. https://doi.org/10.1080/13555502.2014.965500

» Taylor, T. (2011). CHANGING THE PRISON SYSTEM. Kapiti Monthly Meeting. The Quaker Lecture. The Religious Society of Friends in Aotearoa New Zealand. Wilde, O. (1999). De profundis; Ballad of Reading Gaol and other writings. Wordsworth Editions.

Wilde, O. (1999). The soul of man, and prison writings. Oxford University Press.

Wilde, O. (2007). Collected works of Oscar Wilde: the plays, the poems, the stories and the essays including De Profundis. Wordsworth Editions.

Wilde, O., Baldwin Ross, R., Mason, S., \& Holland, V. B. (n.d.). Full text of "A collection of original manuscripts 
letters \& books of Oscar Wilde including his letters written to Robert Ross from Reading Gaol and unpublished letters poems \& plays formerly in the possession of Robert Ross, C. S. Millard (Stuart Mason). Retrieved December 23, 2019, from Dulau website: https://archive.org/stream/collectionoforig00adulrich/ collectionoforig00adulrich_djvu.txt

»Williams, K. (2009). "A Criminal with a Noble Face": Oscar Wilde's Encounters with the Victorian Gaol by Kristian Williams: Anarchist Studies. Retrieved December 23, 2019, from https://anarchiststudies.org/acriminal-with-a-noble-face-oscar-wildes-encounters-with-the-victorian-gaol-by-kristian-williams/ 


\section{Endnotes}

1 "The Radical MP Henry Du Pré Labouchère (1831-1912) proposed an amendment to make sexual activity between men a crime. This Eleventh Clause of the Criminal Law Amendments Act stated that, 'Any male person who in public or private commits or is a party to the commission of or procures or attempts to procure the commission by any male person of any act of gross indecency with another male person shall be guilty of a misdemeanor and being convicted thereof shall be liable to be imprisoned for any term not exceeding two years with or without hard labor."”

2 For further details, see "Epistola: in Carcere et Vinculis": The Downfall of Oscar Wilde (Presentation). "Wilde's relationship with Lord Alfred Douglas began in the spring of 1892, and resulted in an ongoing affair which caused Wilde's ruin (385). Wilde's relationship with Alfred Douglas was an amorous relationship which proved fidelity through economic rather than sexual means, as Douglas drove Wilde to 'acquisition' other young men. Wilde repeatedly paid Douglas's debts and supported him, leading ultimately to bankruptcy. This relationship formed the seed for the later obscenity trials which ruined Wilde."

https://wildedecadence.wordpress.com/2014/03/04/epistola-in-carcere-et-vinculis-the-downfall-of-oscarwilde-presentation/

3 PRISONS ACT 1898, CHAPTER XLI. (1898). An Act to Amend the Prisons Acts.

http://www.irishstatutebook.ie/eli/1898/act/41/enacted/en/print.html .

$4 \quad$ See The National Archives, Prisoners on a Treadwheel at Pentonville Prison 1895. "The work on the treadwheel was to hold on to a bar and walk up the wheel. You did ten minutes on and five off, for eight hours, climbing the equivalent of over 8,000 feet in the process".

http://www.nationalarchives.gov.uk/education/resources/victorian-prison/source-2a/

5 See The National Archives, Prisoners picking oakum.

"Picking oakum was one of the most common forms of hard labour in Victorian prisons. Prisoners were given quantities of old rope, which they had to untwist into many corkscrew strands. They then had to take these individual strands and unroll them, usually by rolling them on their knee using their hands until the mesh became loose".

http://www.nationalarchives.gov.uk/education/prisoner4099/historical-background/enlarge-oakum.html

6 "This approach became fully dominant after the centralization of prison administration and the appointmentof Sir Edmond Du Cane as the Chair of the Prison Commission in 1877. Du Cane sought to establish standard, punitive conditions for all inmates: as the slogan ran, 'Hard Labour, Hard Fare, and Hard Bed'. He thus instituted a system of stages and classes, stratifying the inmate population and ordering each one's prison career according to a uniform, rational plan, a progression that conceptually linked greater discipline and increased comfort".

7 See the British Library.

"Its publication gave the author's name as C.3.3 (Wilde's number in Reading Gaol, his cell being the third on the third floor of Block C)."

https://www.bl.uk/collection-items/the-ballad-of-reading-gaol-by-oscar-wilde.

$8 \quad$ Oscar Wilde Prison Letters [bound manuscript]. Clark Library, Wilde W6 721L R825, 1895-1897 Bound. Page 21d. Reprinted as: Oscar Wilde to Thomas Martin, ca. April 1897, in Complete Letters, 798.

http://anarchiststudies.mayfirst.org/node/335.

$9 \quad$ See The British Library, Manuscript of 'De Profundis' by Oscar Wilde.

'De Profundis' is Latin for 'from the depths'; it comes from the first line of Psalm 130 of the penitential Psalms: 'Out of the depths have I cried unto thee, O Lord'. The writer E. V. Lucas (1868-1938) claimed to have suggested the title; Wilde had suggested Epistola: In Carcere et Vinculis, meaning 'Letter: In Prison and in Chains'.

https://www.bl.uk/collection-items/manuscript-of-de-profundis-by-oscar-wilde.

10 "If a prison does not succeed in deterring an offender who has had experience of its severities from coming back to it again and again, it is not likely to have much influence in deterring the criminally disposed from embarking on a criminal life. On the contrary, the spectacle of an offender going to prison for the fifth, the tenth, the twentieth time, is calculated to encourage the peccant materials in the population rather than to deter them." (Cross, 1971, p.1) 
"Its publication gave the author's name as C.3.3 (Wilde's number in Reading Gaol, his cell being the third on the third floor of Block C)."

https://www.bl.uk/collection-items/the-ballad-of-reading-gaol-by-oscar-wilde.

12 See British Executions, Charles Thomas Wooldridge.

Consider revising, two adjacent quotations separated by a full stop (see suggestion above), "At his trial the jury took just two minutes to find him guilty, despite his attempts to get the charge reduced to manslaughter because of his wife's unfaithfulness. He was sentenced to death and was hanged at Reading Gaol on 7th July 1896. He passed into immortality as the subject of the poem The Ballad of Reading Gaol by Oscar Wilde, who was serving time in Reading Gaol during the execution."

http://www.britishexecutions.co.uk/execution-content.php?key=2394.

13 Here Wilde abandons his characteristic satirical flourishes and writes in an uncompromisingly political voice." (Jarrin, 2008, p. 95)

14 Stokes illustrates that "the 'iron gin' was a trap used to catch wild animals which can be seen as either an image of the prisoners being trapped or the iron bars which enclose the prisoners like an animal pen.", and 'Gyves' as "a portable form of torture by physical incapacitation in which the body was forced by the device into 'impossible' positions."

15 See Prisons Act, 1898.

"Hard labour: 4.-(1) The mode in which sentences of penal servitude or imprisonment with or without hard labour are to be carried out in prisons may be regulated by prison rules. (2) In making such rules, regard shall be had to the sex, age, health, industry, and conduct of the prisoners."

http://www.irishstatutebook.ie/eli/1898/act/41/enacted/en/print.html 